UDK 504.062; 330.15

\title{
A circular economy: an analysis of the businesses awareness level in the Baltic Sea Region countries
}

\author{
Ph.D. Olga Sergienko oisergienko@yandex.ru \\ Ph.D. Anastasia Pavlova nastya.s.pavlova@gmail.com \\ Violetta Savoskula violetta.savoskula@gmail.com \\ ITMO University \\ 191002, Russia, St. Petersburg, Lomonosova ul., 9 \\ Karvinen Meeri meeri.karvinen@aalto.fi \\ D.Sc., professor Sorvari Jaana jaana.sorvari@aalto.fi \\ Aalto University, Finland \\ P.O. Box 15200, 00076 Aalto, Finland \\ Vaira Obuka vaira.obuka@lu.lv \\ D.Sc., professor Māris Kl̦avin̦šs maris.klavins@lu.lv \\ University of Latvia, Riga \\ Blvd 19, Riga 1586, Latvia \\ Karl Hillman Karl.Hillman@hig.se \\ University of Gavle, Sweden \\ 80176, Gävle, Sweden \\ Sakari Autio Sakari.Autio@lamk.fi \\ Lahti University of Applied Science, Finland \\ Niemenkatu 73, 15140, Lahti, Finland
}

Circular economy is a model of production and consumption, which involves sharing, leasing, reusing, repairing, refurbishing and recycling existing materials and products as long as possible. In this way, the life cycle of products is extended. Unlike the traditional linear economic model based on a 'take-make-consume-throw away' pattern, a circular economy is based on the notion that all wastes can be considered as valuable resources in an almost closed loop, where products and the materials they contain are highly valued. In practice, it implies reducing waste to a minimum. Examination of the current knowledge and performance on resource efficiency and circular economy of industrial enterprises in companies in the Baltic Sea Region-in Finland, Sweden, Latvia and St. Petersburg Region, Russia - was in focus in the two parallel twinning international projects "ERREC 2.0» (Environmental Responsibility and Resource Efficiency) and "LARELICE-P» (Preparing Learning about Resource Efficiency Leading into Circular Economy), realized in 2017-2018. The projects received funding from the Intereg Baltic Sea Region program of the European Union and the Swedish Institute, respectively. Project partners included five universities: Aalto University (Finland), Lahti University of Applied Sciences (Finland), University of Gävle (Sweden), University of Latvia, Riga and ITMO University (Russia). The main overall objective of the projects was to increase the level of education among young and elderly people to guarantee skilled work force with a relevant level of awareness in the area of resource efficiency leading to a circular economy. The specific objectives of the projects included there cognition of new technologies, innovations and joint activity models to support skills development in circular economy and resource efficiency in participating regions between companies and higher education institutions (HEIs).Cooperation with businesses will provide the HEIs in the Baltic Sea Region with resource efficiency related research topics corresponding to their industry. In the future projects, these topics will be worked on using different methods to bring together students, companies and university staff to investigate companies' activities and possibilities to make them more resource and environmentally efficient and also economically more competitive. To evaluate the current knowledge and performance on resource efficiency and circular economy, a survey was distributed to51 companies in the project partner countries. In addition, the survey aimed to find out the companies' experiences and willingness to engage in university-industry collaboration. In the survey, about $78 \%$ of the respondents chose sustainability in general (including concepts such as social/environmental/economic sustainability, corporate social responsibility, fair trade etc.) as the most important concepts leading to circular economy. These were followed by the resource efficiency 
concept: (waste minimization, energy efficiency, material efficiency etc.) with $76 \%$ of the responses. The results will promote the sharing of knowledge between universities and companies, offer valuable information on the competences needed in working life, and may lead to new cooperation between Baltic, Nordic and Russian companies and universities.

Keywords: circular economy, resource efficiency, energy efficiency, life cycle, waste, company, university, cooperation, survey.

DOI: $10.17586 / 2310-1172-2018-11-4-125-138$

\title{
Экономика замкнутого цикла: анализ уровня осведомленности бизнеса в странах региона Балтийского моря
}

\author{
Канд. техн. наук Сергиенко О.И. oisergienko@yandex.ru \\ Канд. экон. наук Павлова А.С. nastya.s.pavlova@gmail.com \\ Савоскула В.A. violetta.savoskula@gmail.com \\ Университет ИТМО \\ 191002, Россия, Санкт-Петербург, ул. Ломоносова, д. 9
}

Карвинен Меери meeri.karvinen@aalto.fi

Д-р физ. наук, профессор Сорвари Яна jaana.sorvari@aalto.fi

Университет Аалто

15200, Финляндия, 00076 Аалто

Обука Вайра vaira.obuka@lu.lv

Д-р хим. наук, профессор Клавинс Марис maris.klavins@lu.lv

Университет Латвии

1586, Латвии, Рига, Блвд 19

Хиллман Карл Karl.Hillman@hig.se

Университет Евле

80176, Швеция, Евле

Сакари Аутио Sakari.Autio@lamk.fi

Университет прикладных наук Лахти

15140, Финляндия, Лахти, ул. Ниеменкату 73

Экономика замкнутого цикла - это модель производства и потребления, которая включает в себя обмен, лизин, повторное использование, ремонт, восстановление и переработку существующих материалов и продукции в течение максимально длительного срока. При этом жсизненный цикл продукции увеличивается. В отличие от традиционной линейной экономической модели, основанной на принципе «бери, делай, выбрасывай», экономика замкнутого цикла основана на представлении, что все отходы можсно рассматривать как ценные ресурсы в почти замкнутом цикле, в котором продукция и материалы, имеют высокую ценность. На практике это подразумевает сокращение отходов до минимума. Современные знания и достижения в области ресурсной эффективности и экономики замкнутого цикла на уровне промыщленных предприятий были изучены в компаниях в странах региона Балтийского моря Финляндии, Швеции, Латвии и России (Санкт-Петербург) в рамках двух международных проектовпартнеров «ERREC 2.0; Экологическая ответственность и ресурсная эффективность» и «LARELICE-P; Исследование ресурсной эффективности, ведущей к циркулярной экономике», которые были реализованы одновременно в 2017-2018 г2. при финансовой поддержке европейской программы Intereg Регион Балтийского моря и Шведского института, соответственно. Оба проекта были выполнялись при активном сотрудничестве пяти университетов: Университета Аалто (Финляндия), Университета прикладных наук Лахти (Финляндия), Университета Евле (Швеция), Латвийского университета, г. Рига и Университета ИТМО (Россия). Основной целью проектов являлось повышение уровня образования среди молодежси, гарантирующего квалифицированную рабочую силу. Задачи проектов включали изучение новых технологий, инноваций и моделей совместной деятельности компаний и вузов для развития компетенций в области экономики замкнутого цикла и ресурсоэффективности в участвующцих регионах. В рамках 
проектов был проведен опрос 51 компании в четырех странах для оценки текущих знаний в области экономики замкнутого цикла, достигнутых результатов по повынению ресурсной эффективности, а такюе возможностей сотрудничества университетов и компаний. В качестве наиболее важнной концепции, ведуцей к циркулярной экономике, респонденты выбрали устойчивое развитие в целом (включая такие понятия, как социальная/экологическая/экономическая устойчивость, корпоративная социальная ответственность, справедливая торговля и т. д.), данный вариант выбрали 78,43\% компаний. Следующими по значимости компании выбрали: эффективность использования ресурсов (минимизация отходов, энергоэффективность, эффективность использования материалов и т. д.) - 76,47\%, предотврацение загрязнения воздуха и почвы - 39,22\%, очистка сточных вод - 29,41\% и смягчение/ адаптация к изменению климата - 21,57\%. Полученные результаты способствуют улучиению обмена знаниями между университетами и компаниями, предоставляют ценную информацию о необходимых трудовых компетенциях и могут привести к развитию сотрудничества между балтийскими, скандинавскими и российскими компаниями и университетами.

Ключевые слова: экономика замкнутого цикла, ресурсная эффективность, энергоэффективность, жизненный цикл, отходы, компания, университет, сотрудничество, опрос.

\section{Introduction}

Depletion of natural resources and pollution caused by waste, have increased the importance of circular economy and resource efficiency also in the Baltic Sea Region, a highly heterogeneous area in economic, environmental and cultural terms. The unique features of the Baltic Sea, and its environmental pressures, demand a broad regional approach to combat its long-term deterioration. This fact is acknowledged through a joint action in HELCOM, although there is a need for increased coordination among sectoral policies [1].

The participating countries share many common resources and demonstrate considerable interdependence; however, actions in one area can very quickly have consequences for other parts of the region. In these circumstances, the project area could be a model of regional co-operation where new ideas and approaches can be tested and developed over time as examples of best practices. Within the existing financial and legal frameworks, there are great opportunities for effective action through closer cooperation and co-ordination.

Energy supply and security is a particular concern: even though some countries in the region have substantial indigenous sources of energy, most countries must rely on imports. Therefore, interconnections need to be further developed and diversified to offset possible interruptions. Human relationships are also important and can be strengthened by actions in the fields of education, tourism and health [2].

The concept 'circular economy' is understood as an economy characterized by a restorative and closed nature. Minimization of the consumption of primary raw materials and the volume of processed resources, accompanied by a decrease in the generation and disposal of waste in landfills, is its key element. The literature highlights the following key features of the circular economy: maintaining the balance of natural resources, optimizing resource consumption processes, and fostering economic and environmental efficiency of systems by revealing and designing out negative environmental externalities [13, 14]. However, despite the undertaken regulatory measures both in the European Union and Russia, this theoretical model is not fully implemented into practice. The concept of circular economy needs the involvement of its stakeholders - promoters to be effectively implemented [15].

Besides the concern of saving natural resources, the economic driver to move towards circular economy is important. Circular economy and resource efficiency may improve the competitiveness of companies. EU published the Circular Economy Package at the end of year 2015 [3]. According to the package, regional actions are needed to move towards circular economy. The transition to a circular economy requires systematic changes, e.g. in waste management, and regions play a central role in the process [4]. To close the loops of material streams through recycling of residues, such as agricultural waste and sludge, as well as to add skills and adapt best available techniques (BATs) and innovations, cross-border joint activities are required. The Environmental report of the South-East Finland - Russia ENPI CBC recognizes that companies lack the financial resources or skills to develop environmental matters [5].

In Russia, the transition towards BATs and implementation of modern technologies was initiated in 2014 after the adoption of amendments to the Federal law on Environmental Protection [6]. Since then, a number of pre-standards and additional national standards on the implementation of BAT principle developed by the Russian Bureau of Best Available techniques have been drawn up thus forming a basis for the environmental industrial policy [7].

The BAT reference documents (BREFs) reflect technological parameters, such as consumption of raw materials, energy and water and generation of waste, etc. associated with certain sectors [8, 9].With regard to waste generation, technological parameters are established in all «vertical» BREFs, and in a number of «horizontal» standards for the utilization of waste [10]. Under conditions of a lack of investments aimed at industrial renovation, additional financial support instruments are needed to provide the transition process. Meanwhile, more than $90 \%$ of all municipal solid waste generated in Russia ends up to disposal. The area of land occupied by landfills and unauthorized dumps totals 47.7 
thousand hectares in the Russian Federation. These facts determine the urgent need for an in-depth analysis of circular economy and principles underlying it, as well as a practical implementation of these principles $[11,12]$.

The significance of the relatively complex and new issue of circular economy is reflected on the rapidly changing working life and has created a new demand for knowledge intensive education. The know-how of participating universities Aalto University (Finland), Lahti University of Applied Sciences (Finland), University of Gävle (Sweden) and ITMO University (Russia) addresses this need by supporting the development of skills for the implementation of circular economy and resource efficiency across the border in collaboration between companies and HEIs by introducing new technologies, innovations and joint activity models.

The educational institutions in the Baltic Sea Region are facing the challenge to keep up with the development. Especially those fields of study, which require the understanding of the bigger picture, are changing rapidly. Working with circular economy and resource efficiency requires swift delivery of information to those actors who can influence on their implementation.

Companies face the challenge of obtaining sufficiently competent labor force and supporting the lifelong learning of elderly staff. To support the companies in the transition towards circular economy and more resource efficient working methods, new innovative training needs to be developed. Also, university students are facing common territorial challenges, that is, the challenge of acquiring experience that guarantees employment. To ensure the quality of education, institutions are increasing cooperation with each other and with the labor market. The goal is to respond to the needs of the actual work field.

\section{Methodology of the survey and companies involved}

The survey of the current practices in the companies around the Baltic Sea Region to implement resource efficiency was conducted in 2017-2018. It was realized by sending a questionnaire to companies in varying sectors in Finland, Sweden, Latvia and St. Petersburg, Russia.

Each project partner appointed a person or a team to distribute the questionnaire to selected companies in their country. Since the target was to have responses from around 20 companies per country, it was agreed that the number of companies receiving the questionnaire should be at least double. Moreover, as the main aim of the survey was to find suitable and interested companies for future educational collaboration, it was agreed that each country was free to choose the most suitable companies to contact. This was also to ensure a sufficient response rate. The questionnaire was distributed to selected companies by emails, while some respondents gave their responses orally by telephone.

The survey comprised two main parts: (1) the current knowledge and performance on resource efficiency and (2) experiences and willingness to engage in university-industry collaboration. The first part included the following items or questions:

1. Select up to 3 most important concepts, into which your company is committed at strategic level (please, answer from the point of view of your business operations)

2. Which of the following sustainability-related certificates or standards does your company implement?

3. To what extent has your company implemented the following circular economy-related activities in practice? (Scale $0-5,0=$ not at all, $5=$ To very great extent)

4. Select those phases of the production chain, in which your company implements resource efficiency. Specify also how you implement it in practice into the text box.

5. Select those phases in the production chain, in which your company has some specific development targets related to circular economy, and define the targets briefly into the text box.

Based on the results of the second part of the survey, it was possible to identify what aspects should be taken into account when selecting companies for the next project. The second part of the survey included the following items or questions

6. Does your company have previous experience in collaborating with higher education institutes? Please, select the experience you have, and indicate how many years you have collaborated (options: $<1,1-4,5-10,>10$ years)

7. How satisfied is your company with the collaboration with higher education based on your experiences? (Scale $1-5,1=$ Not at all satisfied, 5=Very satisfied)

8. What kind of collaboration with higher education would your company like to create in the future ?

9. To what kind of resource efficiency-related positions does your company hire recently graduated engineers?

10. Select the five (5) most important skills you expect those graduates to have, from the viewpoint of implementing circular economy/resource-efficiency in your company.

The number and unequal distribution of respondents among the four countries restricted the making of reliable conclusions. Some indicative key results can still be presented and utilized when selecting the companies for the future collaboration. 


\section{Survey results}

According to the results from 51 companies, the most important sustainability concept followed at the strategic level is sustainability in general (including concepts such as social/environmental/economic sustainability, corporate social responsibility, fair trade etc.), which was chosen by $78 \%$ of the companies. This was followed by resource efficiency (waste minimization, energy efficiency, material efficiency etc.) - $76 \%$, prevention of air pollution/contamination of soil $-39 \%$, water pollution control $-29 \%$, and climate change mitigation/adaptation $-22 \%$.

In addition, some $10 \%$ of the respondents mentioned the 'preventing/compensating biodiversity loss' while $4 \%$ of the respondents selected the option 'other sustainability-related concepts'. Only few (4\%) selected the option 'I don't know' (Figure 1).

We can compare the results of this survey with those of the survey «European SMEs and the Circular Economy» commissioned by the European Commission (Directorate-general environment and coordinated by the Directorate-general for communication) [16], implemented in April 2016 and published in June 2016. The key findings of this EU-level survey were (Figure 2):

- almost three quarters of companies (73\%) undertook some circular economy related activities, the most common being minimization of waste by recycling, reuse or selling of waste to another company (55\%), or re-planning of energy use to reduce consumption $(38 \%)$;

- the larger the company, the more likely it has undertaken at least one action towards the implementation of circular economy: $72 \%$ of the smallest companies have done so, compared to $89 \%$ of the companies with $50-250$ employees;

- the higher a company's turnover, the more likely it has undertaken at least one action towards the implementation of circular economy: $69 \%$ with the lowest turnover have done so, compared to $80 \%$ of the companies with the highest turnover.

According to the survey conducted in the ERREC and LARELICE projects, the most common sustainabilityrelated certificates or standards include an environmental management system, ISO 14001 (61\% of the companies), followed by cradle to cradle, EPC energy performance, LEED, BREEAM, FSC, PEFC CE-marking, etc. $(29 \%$ of the companies). Some $29 \%$ of the respondents indicated their company having another equivalent system not listed in the questionnaire. Other certificates included environmental certificates for building, BASTA, ISO 9001:2008 standard, OHSAS 18001, ISO 9001-2008, FSSC 22000 «Food Safety System Certification 22000», GreenZoom (Figure 3).

The practical actions that companies have taken to implement circular economy principle include the following (extent of actions expressed as an average value calculated from each response):

- recycling of waste 3.6 (scale: 0 - not at all, $5=$ To very great extent); great extent);

- energy efficiency (e.g. plans and actions to reduce energy consumption) 3.6 (scale: 0 - not at all, 5=To very

- other material efficiency (e.g. re-designing products or services to minimize material use/using recycled materials, from products to services-strategies) 3.1 (scale: 0 - not at all, $5=$ To very great extent);

- industrial symbiosis with other companies (utilization of surplus/by-products) 2.9 (scale: 0 - not at all, $5=$ To very great extent);

- water efficiency (e.g. reduced use /increased re-use of water) 2.8 (scale: 0 - not at all, 5=To very great extent);

- use of renewable energy 2.3 (scale: 0 - not at all, 5=To very great extent) (Figure 4). 


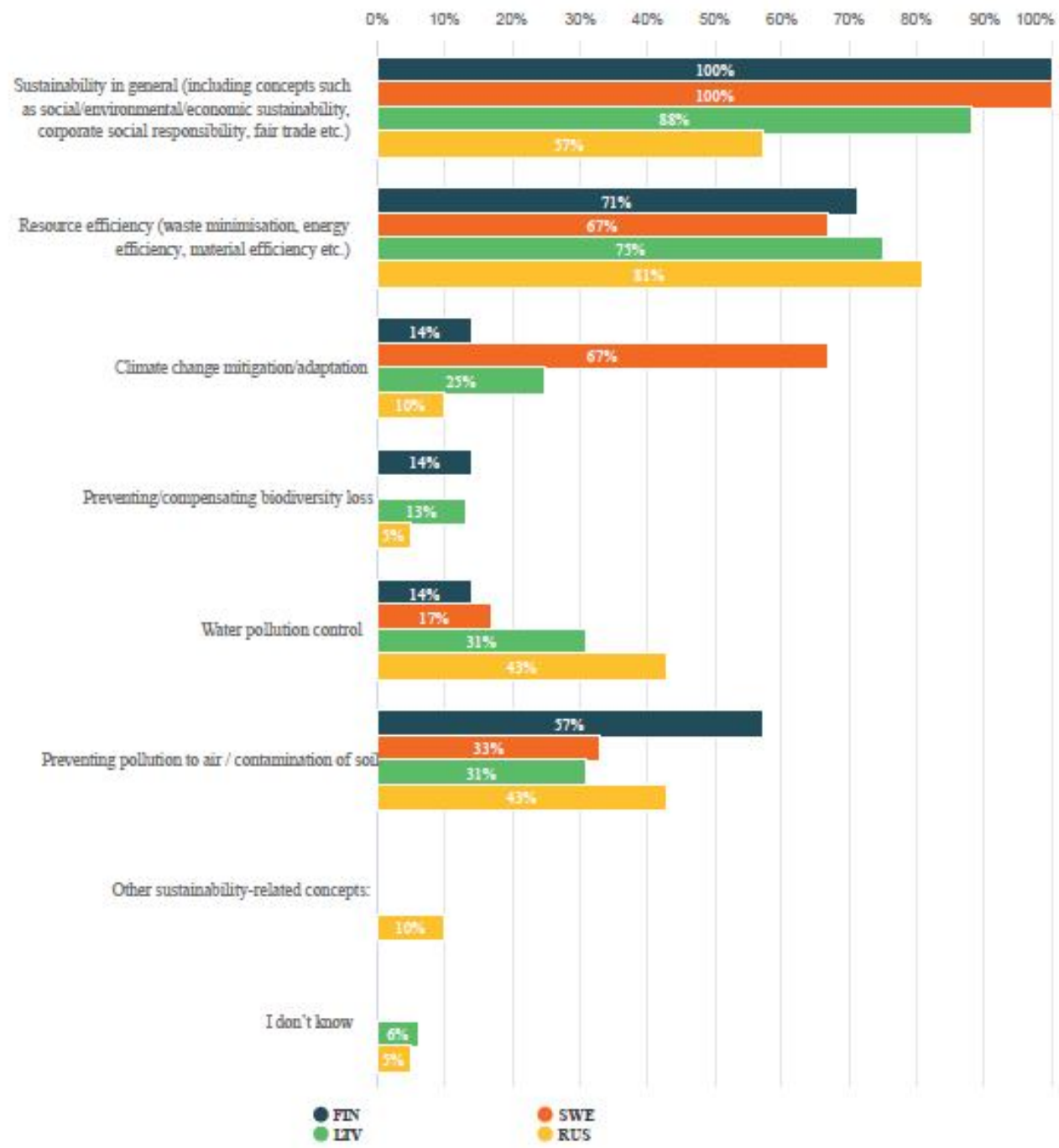

Figure 1-Country-specific results from the survey, question 1: What are three most important concepts, into which your company is committed at the strategic level? (number of responses $=51$ )

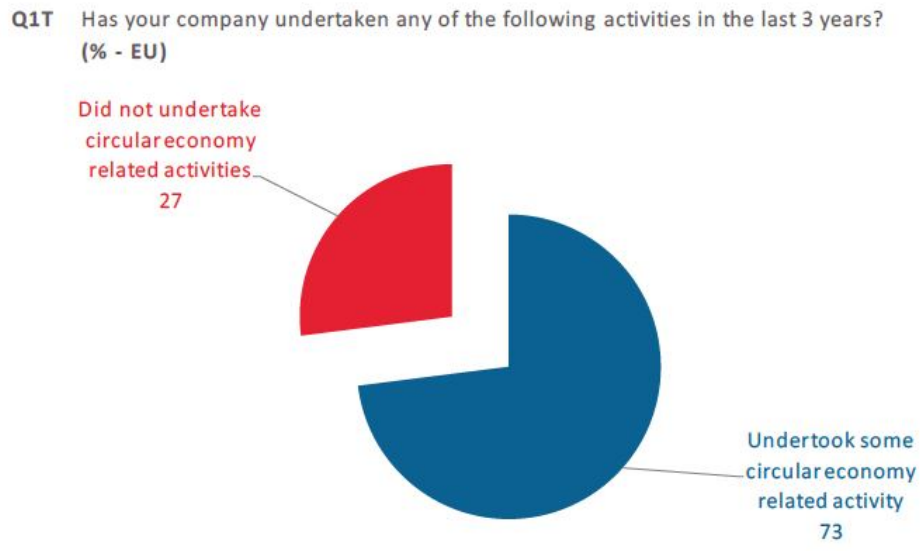

Total base $(N=10,618)$

Figure 2 - Results from the EU-level survey [15].

Question: Has your company undertaken any of the following activities in the last 3 years?

1.1 Re-plan of the way water is used to minimize usage and maximize re-usage; c 1.2 Use of renewable energy;

1.3 Re-plan energy usage to minimize consumption;

1.4 Minimize waste by recycling or reusing waste or selling it to another company;

1.5 Redesign products and services to minimize the use of materials or use recycled materials 


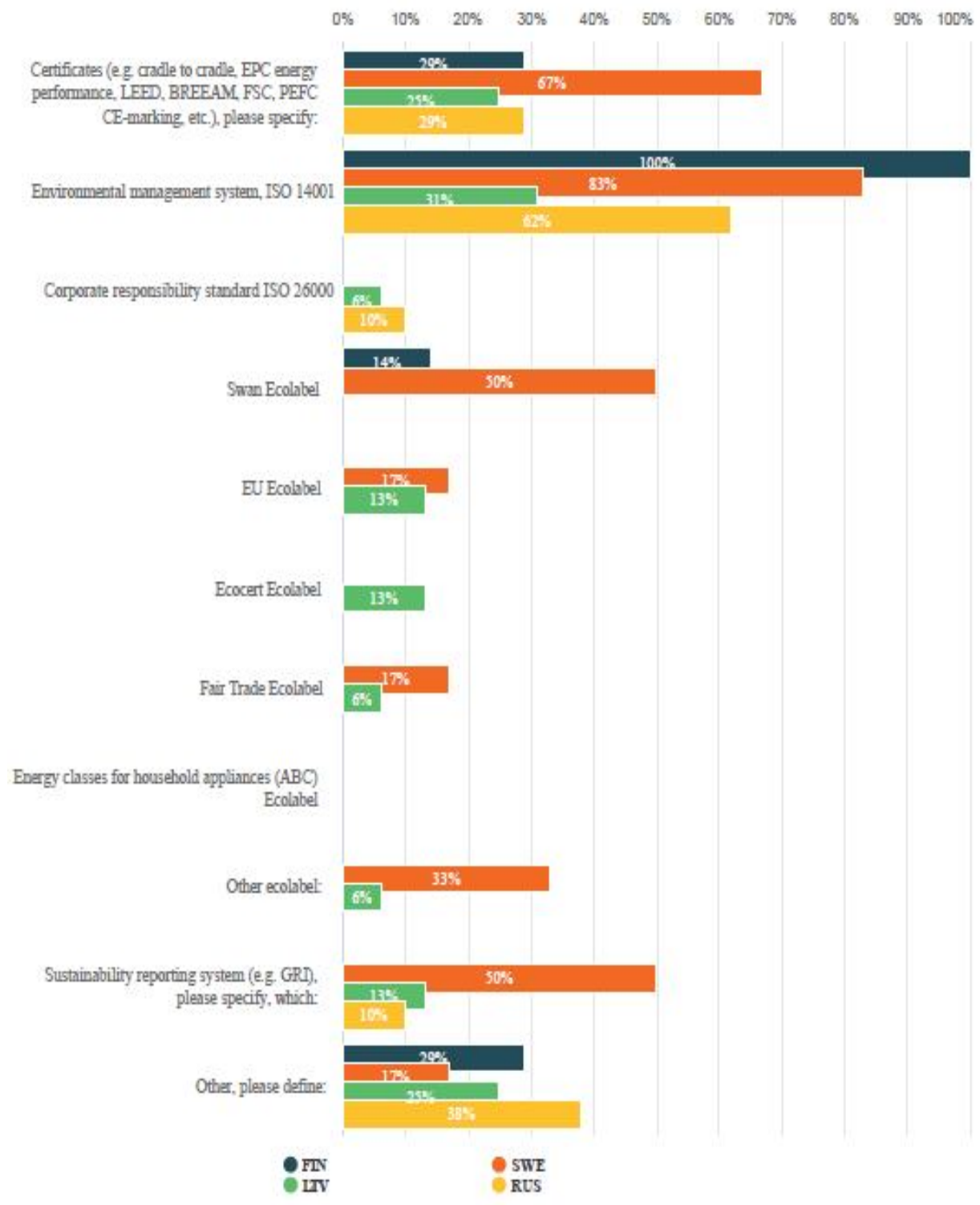

Figure 3 - Country-specific results from the survey, question 2:

Does your company implement sustainability-related certificates or standards?

(Number of responses $=51$ )

Process design, e.g. selection of raw materials, processes and equipment, emerged as the most common phase to implement resource efficiency in the production chain(in $63 \%$ of the companies), with waste management (61\%) being almost equally common (Figure 5). While product/service design (29\%); selection of supplier and contracting (45\%;); product/service deliveries (29\%); and assembly, maintenance and support for the use phase (18\%)were less frequently involved. Some $16 \%$ of respondents selected the option 'Other activities' and specified their response as follows:

- we impact our customers' processes through the planning solutions we offer;

- own wind power plants;

- all suppliers must sign our Code of conduct;

- as a consulting company, the impact is more on the work of the office rather than on the use of resources for customer-oriented activities; using it.

- in the very design of the equipment we pay attention to make our equipment as convenient as possible when 


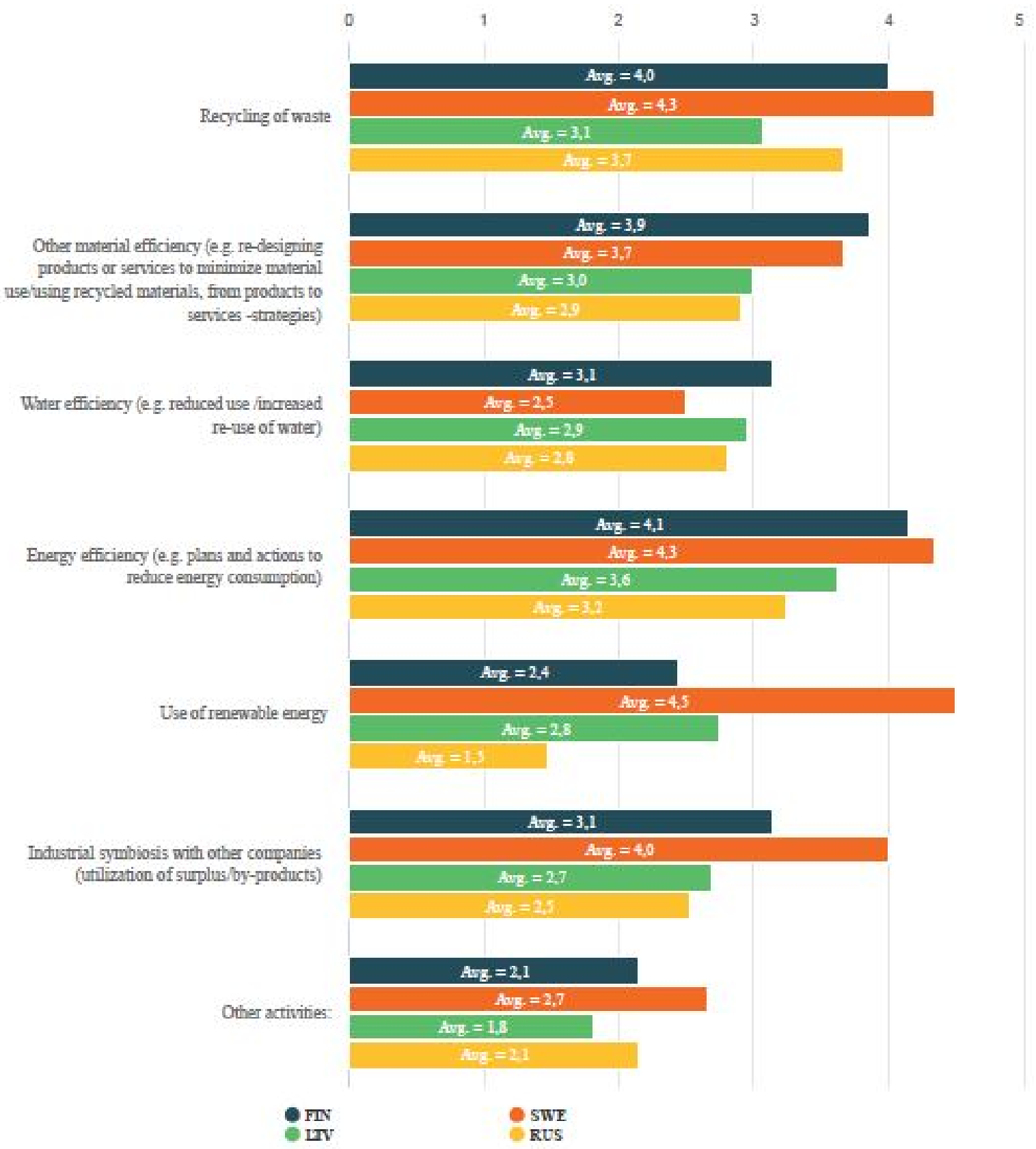

Figure 4-Country-specific results from the survey, question 3:

To what extent has your company implemented the following circular economy-related activities in practice?

(Scale 0-5, 0=not at all, $5=$ To very great extent)(Number of responses $=51$ )

Similarly to the question related to the implementation of resource efficiency, process design (in $51 \%$ of the companies) and waste management (in 55\% of the companies) were the most common phases to have some specific development targets related to circular economy (Figure 6). These were followed by product/service design (35\%); selection of supplier and contracting (20\%); product/service deliveries (18\%); and assembly, maintenance and support for the use phase (16\%).About $20 \%$ of respondents selected the option 'Other' and specified their response as follows:

- all energy use will be renewable;

- Sustainable Development Goals;

- water usage ratio, energy usage ratio;

- the client is the king (at all stages of the chain);

- by providing advice, the appropriate technique is chosen depending on the needs of the client;

- there are no specific targets; 
- short-term and long-term goal is to survive, because in fact we carry out a social function without receiving any support from the state;

- we realize separate waste collection completely at our expense, this activity is unprofitable. We survive by minimizing our own needs and grants «from God.»; Continue in the same spirit.

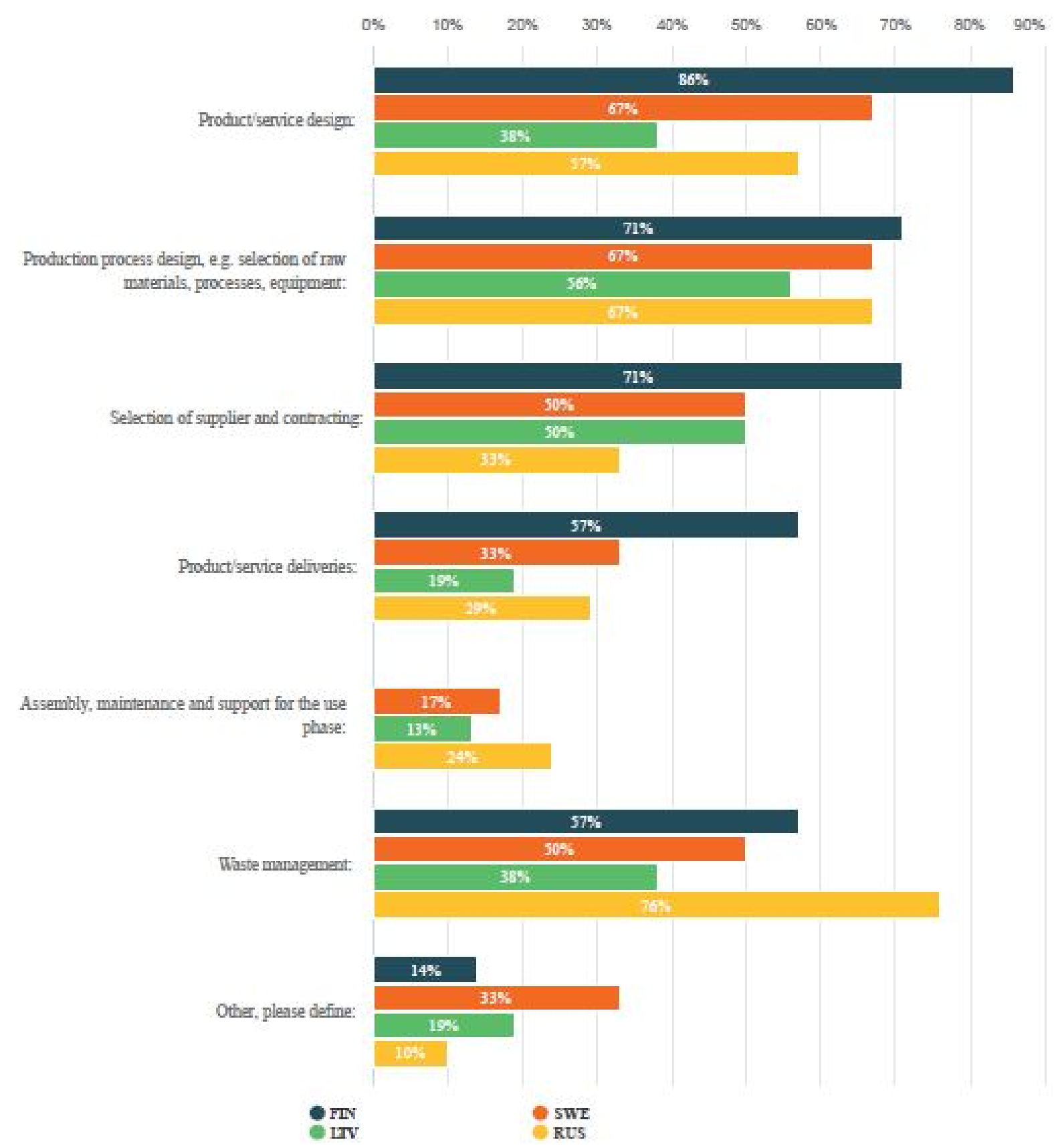

Figure 5 - Country-specific results from the survey, question 4:

Select those phases of the production chain, in which your company implements resource efficiency.

Specify also in the text box how you implement it in practice. (Number of responses $=51$ )

The survey results did not show clearly that the previous experiences and companies' own development targets affect the willingness to and ways of collaborating intensively with higher education.

Most of the participating companies have offered internships and thesis positions to students, and had research collaboration with HEIs (Figure 7). Some of them have also offered lectures and cases to university courses and/or 
received development ideas from courses. Other kind of collaboration that was mentioned in the responses included course planning, joint courses, data analysis, $\mathrm{PhD}$ collaboration and exchange of scientific news.

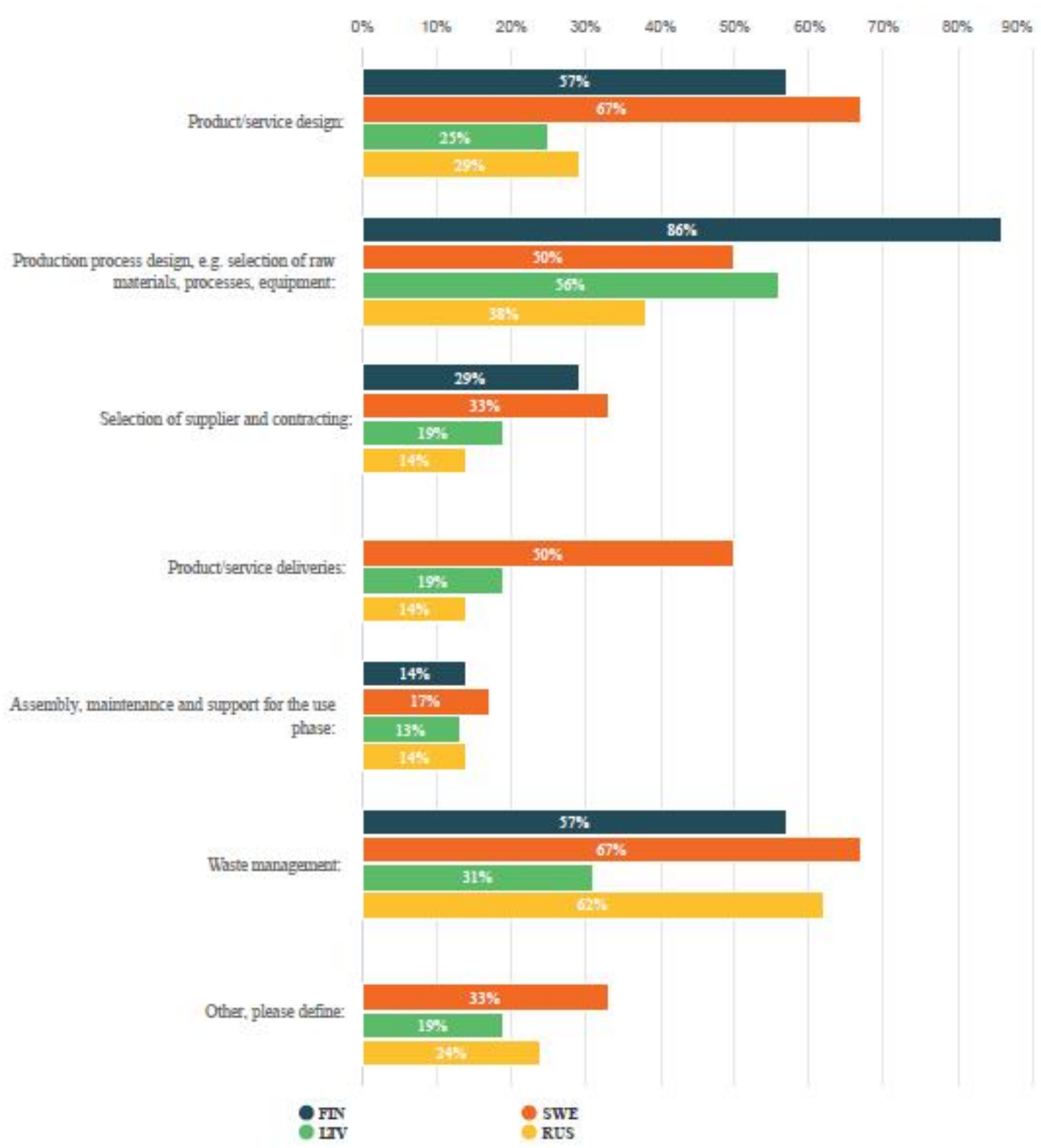

Figure 6 - Country-specific results from the survey, question 5:

Select those phases in the production chain, in which your company has some specific development targets related to circular economy, and define the targets briefly into the text box (Number of responses $=51$ ) 


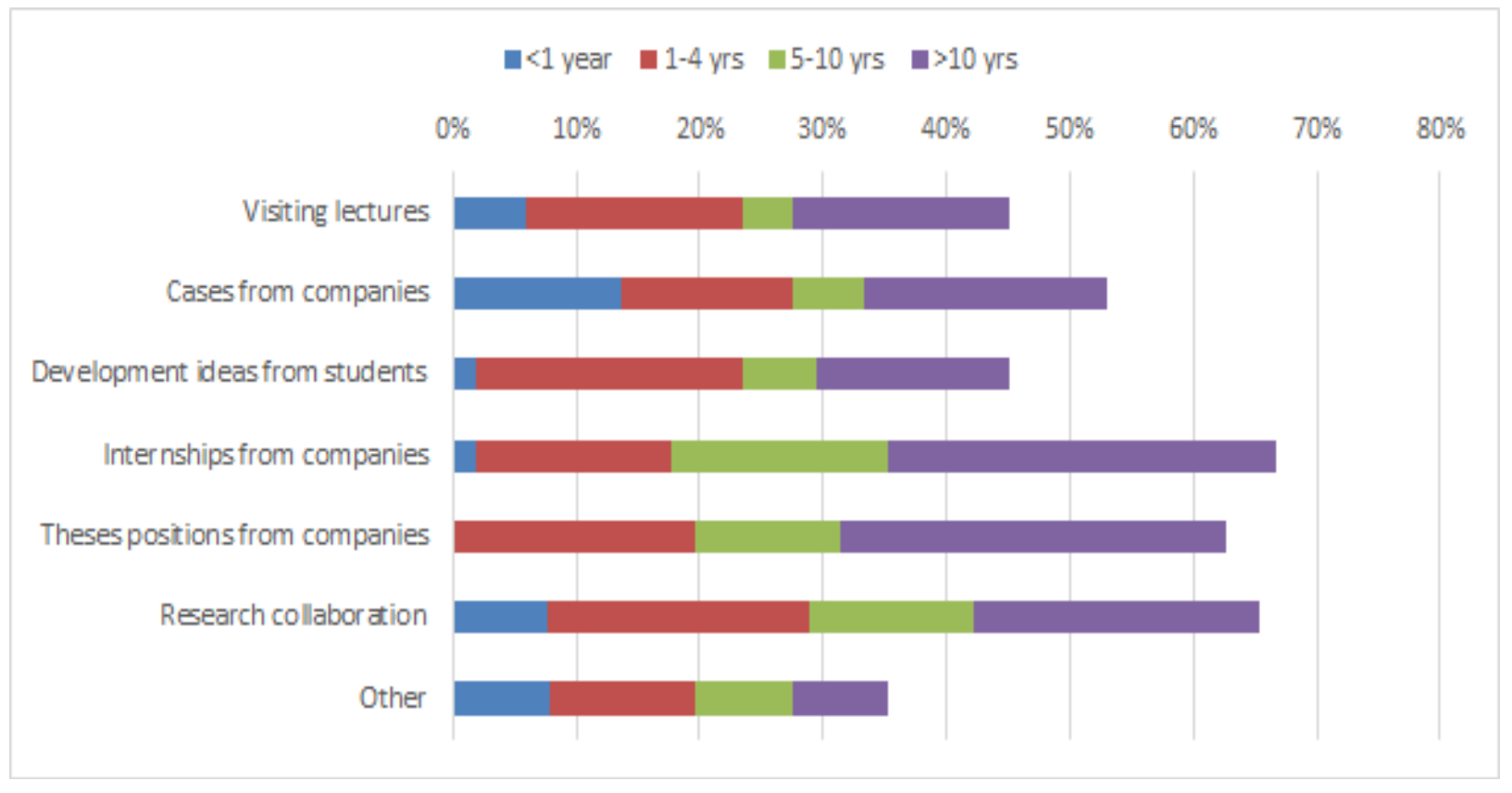

Figure 7 - Country-specific results from the survey, question 6:

Collaboration experience of all the companies (Number of responses $=51$ )

Companies from Russia were most experienced in collaborating with universities, whereas the Swedish companies had slightly less experience (Figure 8). No clear correlation between the extent and frequency of collaboration was observed. Large companies had collaborated mostly in research, and by offering internships and thesis positions, whereas the micro- and medium-sized companies were most experienced in receiving development ideas and offering cases, in relation to their experience.

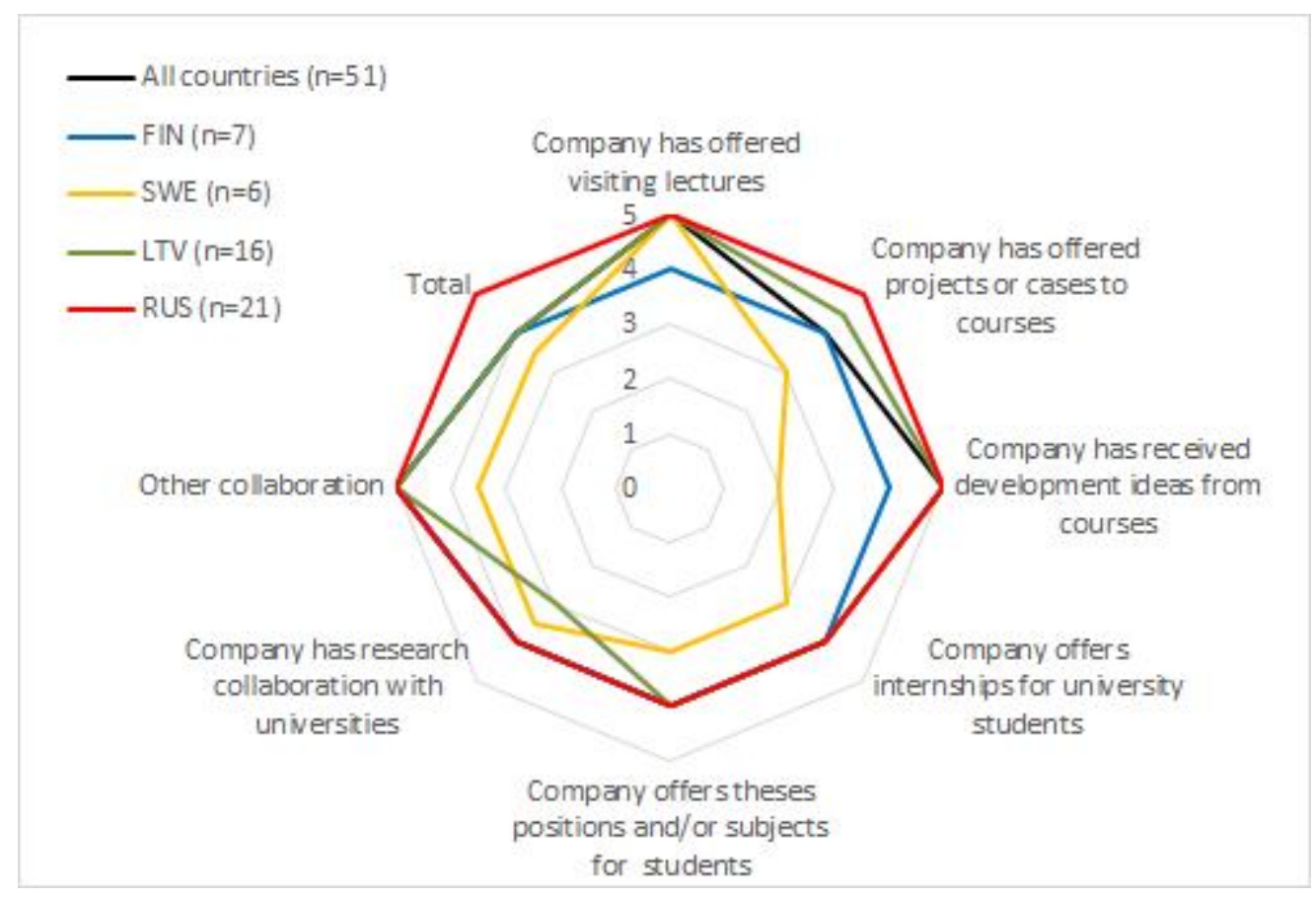

Figure 8 - Country-specific results from the survey, question 8:

Median values of the scores indicating previous experience in participating companies from different countries $0=$ no experience, $5=$ over 10 years of experience $($ Number of responses $=51)$ 
Finally, the companies were asked to select the five most important skills that they expect their future employees (recent graduates from HEIs) to have. The most valued skills were analytical and critical thinking, future orientation, proactivity and initiative, group working skills, and problem solving (Figure 9.).

The four countries differed only slightly in their expectations (Table 1). The skills needed somewhat depended on the positions that the companies had to offer, however.

Table 1

\section{Results from the survey: the top 5 skills of future graduates expected by the companies in different countries}

\begin{tabular}{|c|c|c|c|}
\hline Finland & Sweden & Latvia & Russia \\
\hline Initiative/Proactive & Future orientation & $\begin{array}{c}\text { Analytical and critical } \\
\text { thinking }\end{array}$ & $\begin{array}{c}\text { Future orientation, } \\
\text { ability to anticipate }\end{array}$ \\
\hline Group work & $\begin{array}{c}\text { Analytical and critical } \\
\text { thinking }\end{array}$ & Initiative/Proactive & $\begin{array}{c}\text { Analytical and critical } \\
\text { thinking }\end{array}$ \\
\hline Problem solving & $\begin{array}{c}\text { Organizing, } \\
\text { coordinating, planning }\end{array}$ & $\begin{array}{c}\text { Decision-making, taking } \\
\text { responsibilities }\end{array}$ & $\begin{array}{c}\text { Initiative/Proactive, } \\
\text { flexibility, creativity }\end{array}$ \\
\hline Social skills & Social skills & Problem solving & $\begin{array}{c}\text { Social skills, problem } \\
\text { solving organizing }\end{array}$ \\
\hline $\begin{array}{c}\text { Analytical and critical } \\
\text { thinking }\end{array}$ & $\begin{array}{c}\text { Comprehension/ } \\
\text { Applying theories }\end{array}$ & $\begin{array}{c}\text { Presentation, } \\
\text { communication, time } \\
\text { management, future } \\
\text { orientation }\end{array}$ & \\
\hline
\end{tabular}




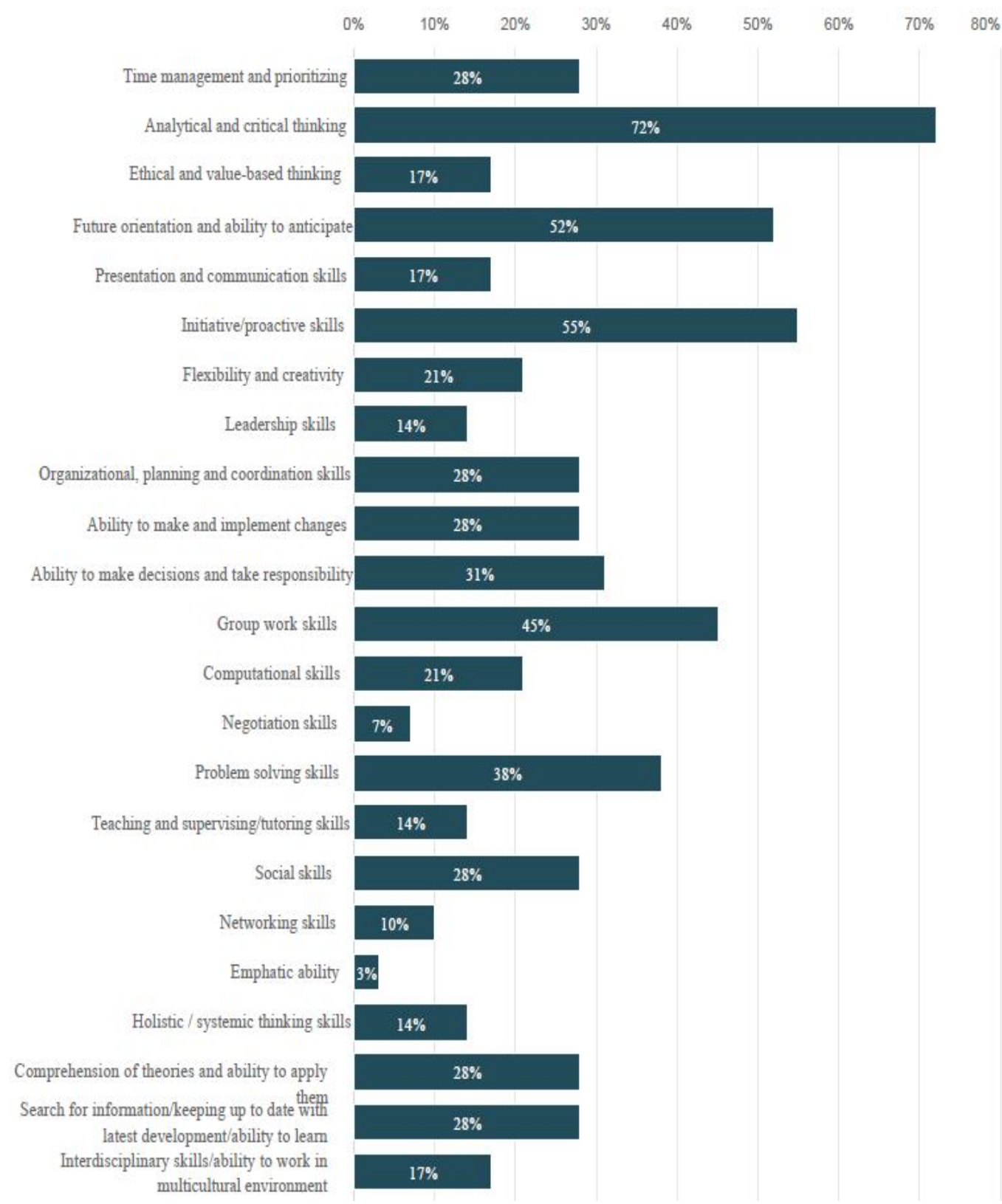

Figure 9 - Country-specific results from the survey, question 10:

The most important skills for future graduates expected by the companies (Number of responses $=51$ )

In all kinds of positions analytical and critical thinking were valued as the most important skill, but for example social skills were specifically highlighted in positions related to customer services, such as project engineers and commercial engineers. Therefore, higher education should offer development possibilities in all these general working life skills, paying special attention to the five skills highlighted by all the companies who took part in the survey.

\section{Conclusion}

In the rapidly changing working life, the importance of circular economy and resource efficiency has increased and brought new demands for a more knowledge intensive education.

Circular economy and resource efficiency are relatively new, complex issues. Nevertheless, due to their importance some efforts have been taken in the Baltic Sea Region countries to support the creation of new knowledge related them.

The results of the survey presented in this paper will be used in the wider twinning projects on university-industry collaboration in the Nordic and Baltic Region and Russia, which started in 2018. The results will promote the sharing of knowledge between universities and companies, offer valuable information on the competences needed in working life, and may lead to new cooperation between Baltic and Nordic companies and universities. 
Carrying out joint studies and meetings with the projects' consortium will strengthen universities-companies cooperation and promote circular economy through resource efficiency in companies around the Baltic Sea. The changes of business awareness level, expected to be achieved through the projects, should be repeatedly surveyed.

\section{Acknowledgement}

This work was supported by Intereg Baltic Sea Region program of the European Union within the project «ERREC 2.0; Environmental Responsibility and Resource Efficiency» and by the Swedish Institute within the project «LARELICE-P; Preparing Learning about Resource Efficiency Leading into Circular Economy».

\section{Reference (Литература)}

1. HELCOMBaltic Sea Action Planadopted on 15 November 2007 in Krakow, Poland by the HELCOM Extraordinary Ministerial Meeting. http:www.helcom.fi/Documents/Baltic\%20sea\%20action\%20plan/BSAP_Final.pdf.

2. Communication from the Commission to the European Parliament, the Council, the European Economic and Social Committee and the Committee of theRegions concerning the European Union Strategy for the Baltic Sea Region // Commission of the European Communities. COM (2009) 248 final-Brussels, 10.6.2009.

3. Circular Economy Package. Turning waste into a resource Moving towards a «circular economy» // Briefing EU Legislation in Progress - $\quad$ European Parliament, December 2014//http:www.europarl.europa.eu/RegData/etudes/BRIE/2014/545704/EPRS_BRI(2014)545704_REV1_EN.pdf.

4. Circular Economy Package. Four legislative proposals on waste // Briefing EU Legislation in Progress - European Parliament, January 2016// http:www.europarl.europa.eu/EPRS/EPRS-Briefing-573936-Circular-economy-packageFINAL.pdf.

5. Environmental report. The South-East Finland - Russia ENPI CBC//https:www.sefrcbc.fi/wpcontent/uploads/sites/6/2016/12/South-East-Finland-Russia-CBC-2014-2020-SEA-in-Finland EN.pdf.

6. Federal law of 21.07.2014 № 219-FZ «On amending Federal law on Environmental Protection and other legislative acts of the Russian Federation».

7. The Russian Bureau of Best Available Techniques//http:burondt.ru/

8. GOST R 56828.14 - 2016 Best Available Techniques. Information and Technical Document (BREF) structure//http:internet-law.ru/gosts/gost/63554/.

9. Best available techniques. Application in the different branches of economy // Ed. O.Y. Chechevatova. - M.: «Pero», 2016. $176 \mathrm{p}$.//http:burondt.ru/informacziya/publikaczii/publikacziya.html?PublishingType=2.

10. Skobelev D.O., Guseva T.V., Chechevatova O.Y., et al. Comparative analysis of drawing up and review of reference documents on Best Available Techniques in the European Union and in the Russian Federation / edited by D.O. Skobelev. - M.: Pero, 2018, 90 p. //http:burondt.ru/informacziya/publikaczii/publikacziya.html?PublishingType=2.

11. Pakhomova N.V., Richter K.K.,Vetrova M.A. Transition to circular economy and closed loop supply chains as driver of sustainable development. - St. Petersburg: Vestnik of St. Petersburg University. Economics. -2017. T/33 N2, PP 244268.

12. Analytical note on the treatment of solid household and industrial waste and on the implementation of pilot projects for waste treatment in the subjects of the Russian Federation. -Rosprirodnadzor, 2017.

13. Delivering the circular economy. A toolkit for policymakers. - Ellen Macarthur Foundation, 2015, 176 p.//https:www.ellenmacarthurfoundation.org/assets/downloads/publications/EllenMacArthurFoundation_PolicymakerToo lkit.pdf.

14. Circularity indicators. An approach to measuring circularity. Methodology. - Ellen Macarthur Foundation, 2015// https://www.ellenmacarthurfoundation.org/assets/downloads/insight/Circularity-Indicators_Project-

Overview_May2015.pdf.

15. Growth within: A circular economy vision for a competitive Europe. - Ellen Macarthur Foundation, 2015//https://www.ellenmacarthurfoundation.org/assets/downloads/publications/EllenMacArthurFoundation_GrowthWithin_July15.pdf.

16. European SMEs and the Circular Economy. Report.- Flash Eurobarometer 441 - TNS Political \& Social. - 2016. http:ec.europa.eu/environment/green-growth/docs/fl_441_sum_en.pdf. 